Correspondence

Tatyana Sokolova tatso@mail.ru

\title{
Thermincola carboxydiphila gen. nov., sp. nov., a novel anaerobic, carboxydotrophic, hydrogenogenic bacterium from a hot spring of the Lake Baikal area
}

\author{
Tatyana G. Sokolova, Nadezhda A. Kostrikina, Nikolai A. Chernyh, \\ Tatjana V. Kolganova, Tatjana P. Tourova \\ and Elizaveta A. Bonch-Osmolovskaya \\ Institute of Microbiology, Russian Academy of Sciences, Prospekt 60, let Oktyabrya 7/2, \\ 117811 Moscow, Russia
}

\begin{abstract}
A novel anaerobic, thermophilic, alkalitolerant bacterium, strain $2204^{\top}$, was isolated from a hot spring of the Baikal Lake region. The cells of strain $2204^{\top}$ were straight rods of variable length, Gram-positive with an S-layer, motile with one to two lateral flagella, and often formed aggregates of 3-15 cells. The isolate was shown to be an obligate anaerobe oxidizing $\mathrm{CO}$ and producing equimolar quantities of $\mathrm{H}_{2}$ and $\mathrm{CO}_{2}$ according to the equation $\mathrm{CO}+\mathrm{H}_{2} \mathrm{O} \rightarrow \mathrm{CO}_{2}+\mathrm{H}_{2}$. No organic substrates were used as energy sources. For lithotrophic growth on $\mathrm{CO}, 0.2 \mathrm{~g}$ acetate or yeast extract $\mathrm{I}^{-1}$ was required but did not support growth in the absence of $\mathrm{CO}$. Growth was observed in the temperature range $37-68^{\circ} \mathrm{C}$, the optimum being $55^{\circ} \mathrm{C}$. The $\mathrm{pH}$ range for growth was $6 \cdot 7-9 \cdot 5$, the optimum $\mathrm{pH}$ being $8 \cdot 0$. The generation time under optimal conditions was $1.3 \mathrm{~h}$. The DNA G $+\mathrm{C}$ content was $45 \mathrm{~mol} \%$. Penicillin, erythromycin, streptomycin, rifampicin, vancomycin and tetracycline completely inhibited both growth and CO utilization by strain $2204^{\top}$. Thus, isolate $2204^{\top}$ was found to be the first known moderately thermophilic and alkalitolerant $\mathrm{H}_{2}$-producing anaerobic carboxydotroph. The novel bacterium fell within the cluster of the family Peptococcaceae within the low- $\mathrm{G}+\mathrm{C}$-content Gram-positive bacteria, where it formed a separate branch. On the basis of morphological, physiological and phylogenetic features, strain $2204^{\top}$ should be assigned to a novel genus and species, for which the name Thermincola carboxydiphila gen. nov., sp. nov. is proposed. The type strain is strain $2204^{\top}\left(=\mathrm{DSM} 17129^{\top}=\right.$ VKM B-2283 $\left.{ }^{\top}=\mathrm{JCM} 13258^{\top}\right)$.
\end{abstract}

Anaerobic, thermophilic, carboxydotrophic, hydrogenogenic prokaryotes are represented by several phylogenetically diverse prokaryotes which grow lithotrophically on $\mathrm{CO}$, performing the metabolic reaction $\mathrm{CO}+\mathrm{H}_{2} \mathrm{O} \rightarrow \mathrm{CO}_{2}+\mathrm{H}_{2}$ $\left(\Delta \mathrm{G}^{0}=-20 \mathrm{~kJ}\right)$ : Carboxydothermus hydrogenoformans (Svetlichny et al., 1991), Caldanaerobacter subterraneus subsp. pacificus (Sokolova et al., 2001; Fardeau et al., 2004), Carboxydocella thermautotrophica (Sokolova et al., 2002) and Thermosinus carboxydivorans (Sokolova et al., 2004a). Recently, a hyperthermophilic archaeon of the genus Thermococcus able to grow by the same reaction was isolated from deep-sea hot vents (Sokolova et al., 2004b). All these organisms are neutrophiles, growing in the $\mathrm{pH}$ range $6 \cdot 5-7 \cdot 8$. To date, alkalitolerant, $\mathrm{CO}$-utilizing,

Published online ahead of print on 27 May 2005 as DOI 10.1099/ ijs.0.63299-0.

The GenBank/EMBL/DDBJ accession number for the 16S rRNA gene sequence of Thermincola carboxydiphila strain $2204^{\top}$ is AY603000.
$\mathrm{H}_{2}$-producing, thermophilic anaerobes have not been reported. Here we describe a novel anaerobic, moderately thermophilic, moderately alkaliphilic, $\mathrm{CO}$-oxidizing, $\mathrm{H}_{2-}$ producing bacterium isolated from an alkaline hot spring of the Baikal Lake area.

Samples of hot water, mud and cyanobacterial mats were taken from freshwater thermal springs of the Baikal Lake area; the $\mathrm{pH}$ of the water varied from 6.8 to $9 \cdot 5$, and the original temperatures were in the range $51-72{ }^{\circ} \mathrm{C}$. The samples were taken anaerobically in tightly stoppered bottles and transported to the laboratory at ambient temperature.

Unless otherwise mentioned, the medium used for enrichments and cultures contained the following $\left(\mathrm{g} \mathrm{l}^{-1}\right)$ : $\mathrm{NH}_{4} \mathrm{Cl}$ (1), $\mathrm{MgCl}_{2} \cdot 2 \mathrm{H}_{2} \mathrm{O}(0 \cdot 33), \mathrm{CaCl}_{2} \cdot 6 \mathrm{H}_{2} \mathrm{O}(0 \cdot 1), \mathrm{KCl}(0 \cdot 33)$, $\mathrm{KH}_{2} \mathrm{PO}_{4}(0 \cdot 5), 1 \mathrm{ml}$ trace mineral solution (Kevbrin \& Zavarzin, 1992), $1 \mathrm{ml}$ vitamin solution (Wolin et al., 1963) and resazurin (0.001). $\mathrm{NaHCO}_{3}\left(0 \cdot 5 \mathrm{~g} \mathrm{l}^{-1}\right), \mathrm{Na}_{2} \mathrm{CO}_{3}$ 
$\left(0 \cdot 5 \mathrm{~g} \mathrm{l}^{-1}\right), \quad \mathrm{Na}_{2} \mathrm{~S} .9 \mathrm{H}_{2} \mathrm{O} \quad\left(1 \mathrm{~g} \mathrm{l}^{-1}\right)$ and sodium acetate $\left(2 \mathrm{~g} \mathrm{l}^{-1}\right)$ were added after boiling and cooling of the medium under the flow of nitrogen, and the $\mathrm{pH}$ was adjusted to $8 \cdot 5-9 \cdot 0$ with $5 \mathrm{M} \mathrm{HCl}$. Samples $(10 \mathrm{ml})$ of the medium were placed into $50 \mathrm{ml}$ bottles and the headspaces were filled with $100 \% \mathrm{CO}$ at atmospheric pressure. The incubation temperature was $55^{\circ} \mathrm{C}$. Growth was determined using light microscopy (MBI-3 microscope; LOMO) and GLC detection (GLC-Chrom 5; Laboratorni Přistrozhe Praha) of $\mathrm{CO}$ utilization and gaseous growth-product formation (Sokolova et al., 2001). After incubation at $55^{\circ} \mathrm{C}$ on the medium with $\mathrm{CO}$, several samples produced significant microbial growth. In most cases, short oval rods were predominant. From the sample of mud and cyanobacterial mat from a hot spring on the bank of the Bolshaya River (Barguzin Reserve), an enrichment culture was obtained that grew at $\mathrm{pH} 9 \cdot 0$ by the utilization of $\mathrm{CO}$ and the production of equimolar quantities of $\mathrm{H}_{2}$ and $\mathrm{CO}_{2}$. After 7 days incubation, in the stationary growth phase, the gas pressure increased 1.5-2-fold and the $\mathrm{pH}$ of the medium changed to neutral. The enrichment was used for further purification. After a number of serial-dilution transfers, colonies were obtained in roll-tubes prepared in $15 \mathrm{ml}$ Hungate tubes on the same medium solidified by $5 \%$ agar, with $\mathrm{CO}$ in the gas phase. Round, white, semi-transparent colonies (up to $1 \mathrm{~mm}$ in diameter) developed after 5 days incubation at $55^{\circ} \mathrm{C}$. Well-separated colonies were transferred to the same liquid medium as that used for the enrichment. A pure culture was obtained and designated strain $2204^{\mathrm{T}}$.

Electron microscopy (JEM-100C apparatus; JEOL) and light microscopy were carried out as described previously (Sokolova et al., 2002). The ability of the novel isolate to use diverse energy substrates was tested with the same liquid mineral medium (both in the presence of $0.5 \mathrm{~g}$ yeast extract $1^{-1}$ and in its absence) containing possible substrates at $2 \mathrm{~g} \mathrm{l}^{-1}$ (final concentration), with $100 \% \mathrm{~N}_{2}$ as the gas phase. Possible electron acceptors were added at a concentration of $2 \mathrm{~g} \mathrm{l}^{-1}$ (or $10 \mathrm{~g} \mathrm{l}^{-1}$ in the case of elemental sulfur). Ferric iron hydromorphic oxide $(90 \mathrm{mM})$ was added to the same medium devoid of $\mathrm{Na}_{2} \mathrm{~S} .9 \mathrm{H}_{2} \mathrm{O}$. The cell density was determined by direct cell counting using a phase-contrast microscope at a magnification of $\times 675$.

The influence of the following antibiotics $\left(50 \mu \mathrm{g} \mathrm{ml}^{-1}\right)$ on growth was tested on the medium with $\mathrm{CO}$ as the gas phase: penicillin, erythromycin, streptomycin, rifampicin, vancomycin and tetracycline.

DNA was prepared as described by Marmur (1961). The DNA G + C content was determined by means of meltingpoint analysis (Marmur \& Doty 1962), using Escherichia coli $\mathrm{K}-12 \mathrm{DNA}$ as a reference.

$16 \mathrm{~S}$ rRNA gene amplification, sequencing and sequence analyses were done as described previously (Sokolova et al., 2002).
The cells of isolate $2204^{\mathrm{T}}$ were straight, thick rods with rounded ends, about $0 \cdot 5 \mu \mathrm{m}$ wide and $0 \cdot 6-3 \cdot 0 \mu \mathrm{m}$ long. The cells were motile and single or in short chains of three to five cells; sometimes cells formed aggregates of up to 15 cells. Spores were never observed in cultures. Cultures were not transferable after $5 \mathrm{~min}$ heat treatment at $100^{\circ} \mathrm{C}$. Electron microscopy of whole cells showed the presence of one or two lateral flagella (Fig. 1a). Ultrathin sections revealed Gram-positive cell-wall structure and a globular S-layer (Fig. 1b). The cytoplasmic membrane was often invaginated (Fig. 1b).

Growth of isolate $2204^{\mathrm{T}}$ occurred within the temperature range $37-68^{\circ} \mathrm{C}$, the optimum being at $55^{\circ} \mathrm{C}$; no growth was observed at 30 or $70^{\circ} \mathrm{C}$. Strain $2204^{\mathrm{T}}$ grew at pH values in the range $6 \cdot 7-9 \cdot 5$; the $\mathrm{pH}$ optimum for growth was $8 \cdot 0$.

Isolate $2204^{\mathrm{T}}$ grew in an atmosphere of $100 \% \mathrm{CO}$ on medium containing $0 \cdot 2 \mathrm{~g}$ yeast extract $\mathrm{l}^{-1}$ or $0 \cdot 2 \mathrm{~g}$ sodium

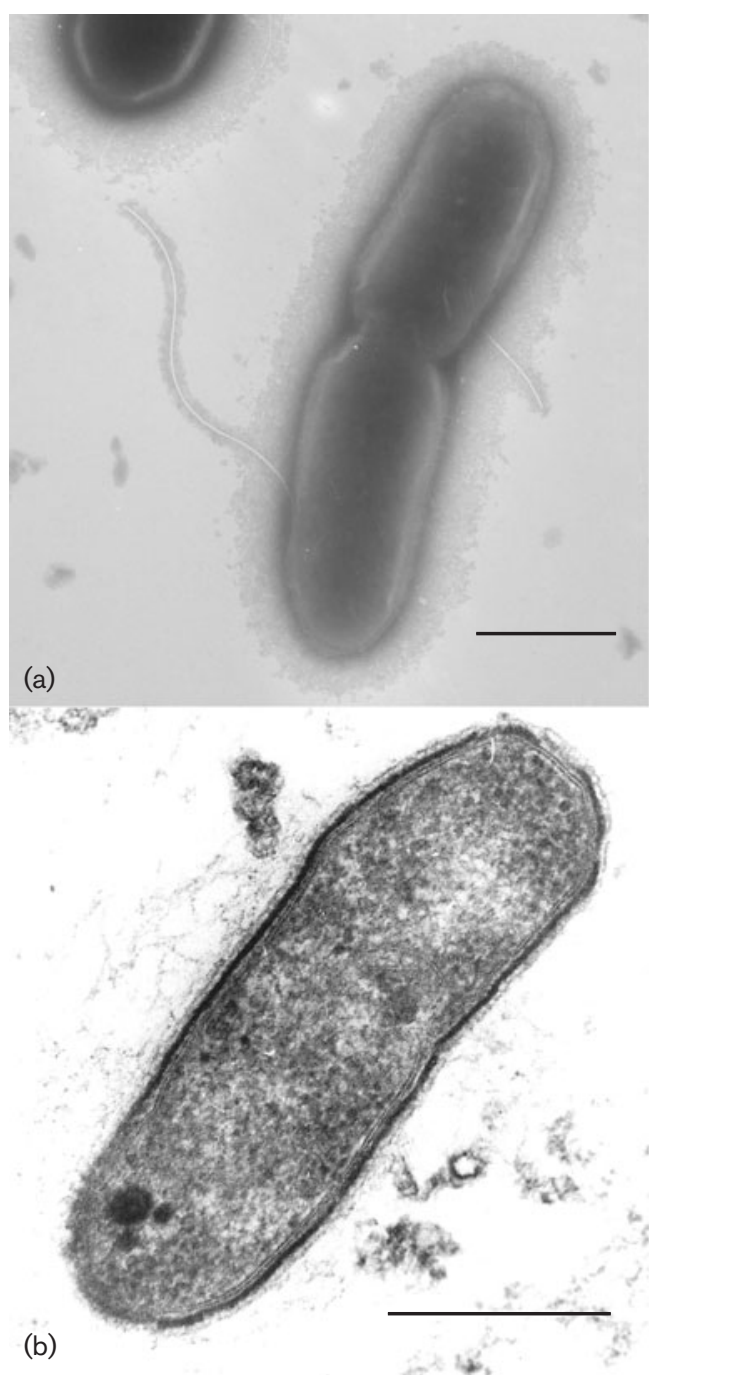

Fig. 1. Electron micrographs of cells of strain $2204^{\top}$. (a) Negative staining; (b) thin section. Bars, $0.5 \mu \mathrm{m}$. 
acetate $\mathrm{l}^{-1}$. CO oxidation was coupled with equimolar $\mathrm{H}_{2}$ and $\mathrm{CO}_{2}$ formation, like the $\mathrm{CO}$ oxidation of previously described anaerobic hydrogenogenic bacteria (Svetlichny et al., 1991; Sokolova et al., 2001, 2002). Neither methane formation nor acetate formation was detected during the growth of isolate $2204^{\mathrm{T}}$ on CO. Either yeast extract or sodium acetate $\left(0.2 \mathrm{~g} \mathrm{l}^{-1}\right)$ was found to be required for growth. The generation time under optimal growth conditions $\left(55^{\circ} \mathrm{C}\right.$, pH $\left.8 \cdot 0\right)$ was $1 \cdot 3 \mathrm{~h}^{-1}$. Strain $2204^{\mathrm{T}}$ was unable to grow organotrophically on peptone or yeast extract or on starch, cellulose, cellobiose, sucrose, maltose, ribose, xylose, lactose, glucose, galactose, fructose, mannitol, sorbitol, pyruvate, acetate, formate, lactate, succinate, methanol, ethanol or glycerol. No growth was observed on an $\mathrm{H}_{2} / \mathrm{CO}_{2}$ gas mixture $(80: 20)$, on $\mathrm{H}_{2}$ or $\mathrm{CO}$ with ferric iron or on $\mathrm{H}_{2}$ or lactate with fumarate in the usual liquid mineral medium supplemented with $0.2 \mathrm{~g}$ sodium acetate $1^{-1}$ and 0.5 g yeast extract $l^{-1}$. No growth was observed on peptone, yeast extract, sucrose, pyruvate, acetate, formate, lactate, succinate, methanol, ethanol or glycerol in the presence of elemental sulfur, sulfate, thiosulfate or ferric iron. Elemental sulfur, thiosulfate, sulfate and nitrate did not stimulate growth and were not reduced during growth on $\mathrm{CO}$.

Penicillin, erythromycin, streptomycin, rifampicin, vancomycin and tetracycline completely inhibited both growth and $\mathrm{CO}$ utilization.

The DNA G + C content of strain $2204^{\mathrm{T}}$ was $45 \cdot 4 \pm 1 \mathrm{~mol} \%$. The 16S rRNA gene sequence (1444 nt, corresponding to positions 38-1485 of E. coli numbering) was determined for strain $2204^{\mathrm{T}}$. Preliminary comparisons using BLAST (http://www.ncbi.nih.gov/BLAST/) performed with representatives of the domain Bacteria revealed that the novel isolate was a member of the Bacillus-Clostridium subphylum of Gram-positive bacteria but was not phylogenetically related to any named organism. The closest match $(94 \%$ similarity) was with an uncultured clone, SHA-15, from an anaerobic 1,2-dichloropropane-dechlorinating mixed culture (Schlötelburg et al., 2000). The closest organism of the species with validly published names ( $93 \%$ similarity) was Pelotomaculum thermopropionicum (Imachi et al., 2000).

Several phylogenetic trees were constructed by changing the compositions of reference organisms belonging to the Clostridium group. Regions of alignment uncertainties due to the presence of long inserts in $16 \mathrm{~S}$ rRNA gene sequences around positions 80,1040, 1140 and 1440 (E. coli numbering) of some members of this group (Rainey et al., 1993; Slobodkin et al., 1999) were omitted from sequence analyses. According to the phylogenetic analysis, the novel strain $2204^{\mathrm{T}}$ fell within the radiation of the family Peptococcaceae. A final comparison of $1327 \mathrm{nt}$ of $16 \mathrm{~S}$ rRNA gene sequences of strain $2204^{\mathrm{T}}$ and 40 reference strains of the family Peptococcaceae was made and used for the reconstruction of a phylogenetic tree and the calculation of sequence similarity. In a phylogenetic tree constructed by using

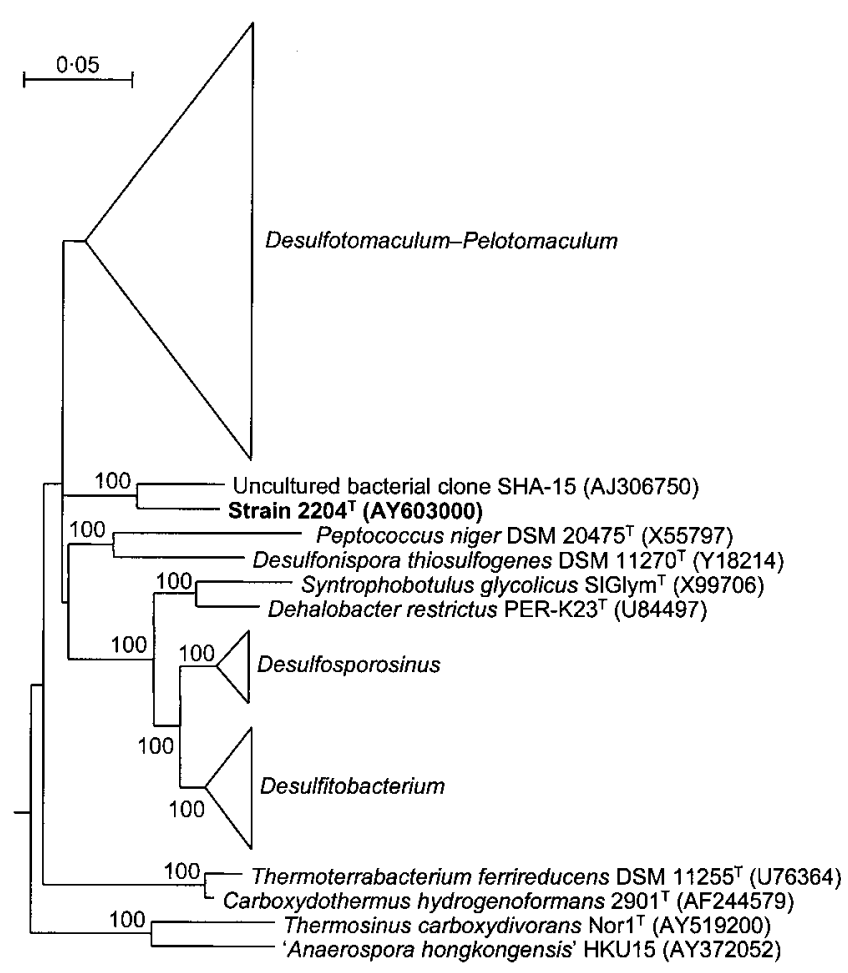

Fig. 2. Phylogenetic position of strain $2204^{\top}$ in the tree of the family Peptococcaceae, constructed by the neighbour-joining method from a comparison of 16S rRNA gene sequences. Clostridium butyricum was used as the outgroup (not shown). Bootstrap values (from 100 replications) are shown at branch points; values greater than 95 were considered significant. Bar, 5 substitutions per 100 nt (Jukes \& Cantor, 1969).

the neighbour-joining algorithm (Jukes \& Cantor, 1969) (Fig. 2), strain $2204^{\mathrm{T}}$ was not clustered exactly with any genus or species of the family Peptococcaceae, including the CO-utilizing hydrogenogens Carboxydothermus hydrogenoformans and Thermosinus carboxydivorans. The additional trees constructed by using other treeing algorithms, including option 'transversion only' for thermophilic organisms, had the same topology (data not shown). The level of sequence similarity of strain $2204^{\mathrm{T}}$ was relatively low and almost equal for all reference strains $(82 \cdot 4-$ $88 \cdot 3 \%$ ). Strain $2204^{\mathrm{T}}$ formed a single cluster with maximal bootstrap support only with uncultured clone SHA-15 (Schlötelburg et al., 2000); the level of similarity of complete $16 \mathrm{~S}$ rRNA gene sequences was $92.9 \%$, so this clone may represent a micro-organism phylogenetically related to strain $2204^{\mathrm{T}}$.

Strain $2204^{\mathrm{T}}$ represents the physiological group of anaerobic carboxydotrophic, hydrogenogenic thermophiles. $\mathrm{CO}$ was found to be the sole source of energy for this isolate. The same is true for Carboxydocella thermautotrophica (Sokolova et al., 2002); however, strain $2204^{\mathrm{T}}$ could not grow autotrophically, requiring acetate or yeast extract. All previously described carboxydotrophic hydrogenogens are 


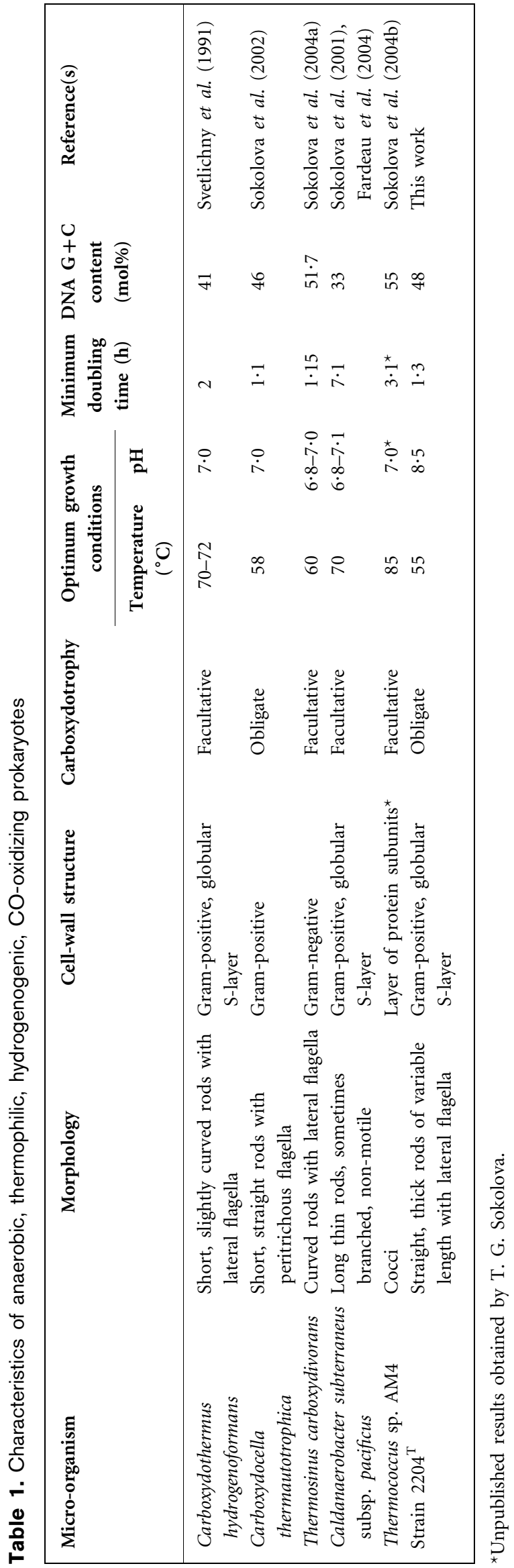

neutrophiles; strain $2204^{\mathrm{T}}$, which grows at $\mathrm{pH}$ values in the range $6 \cdot 7-9 \cdot 5$, is the first alkalitolerant representative of this group (Table 1). According to $16 \mathrm{~S}$ rRNA gene analyses, strain $2204^{\mathrm{T}}$ forms a new separate line of descent within the low-G + C-content Gram-positive subdivision of the Bacteria and could not be assigned to any genus with a validly published name. Thus, we propose a novel genus for it, namely Thermincola, with Thermincola carboxydiphila as the type species.

\section{Description of Thermincola gen. nov.}

Thermincola (Therm.in' co.la. Gr. adj. thermos hot; L. fem. n. incola inhabitant; N.L. fem. n. Thermincola inhabitant of a hot spring).

Cells are non-spore-forming rods. Cell wall is of the Grampositive type. Anaerobic, thermophilic bacteria. Capable of growth by anaerobic $\mathrm{CO}$ oxidation, producing molecular hydrogen and $\mathrm{CO}_{2}$. Does not grow by fermentation of organic substrates. The type species is Thermincola carboxydiphila. Habitat: terrestrial hot springs.

\section{Description of Thermincola carboxydiphila sp. nov.}

Thermincola carboxydiphila (car.bo.xy.di.phi'la. N.L. neut. n. carboxydum carbon monoxide; Gr. adj. philos loving; N.L. fem. adj. carboxydiphila loving carbon monoxide).

Cells are straight, thick rods, with rounded ends, about $0.5 \mu \mathrm{m}$ wide and $0 \cdot 6-3 \cdot 0 \mu \mathrm{m}$ long. Motile due to one or two lateral flagella. Cell wall is of the Gram-positive type. Obligately anaerobic. Grows in the temperature range $37-68^{\circ} \mathrm{C}$, with an optimum at $55^{\circ} \mathrm{C}$. Alkalitolerant: $\mathrm{pH}$ range from $6 \cdot 7$ to $9 \cdot 5$, with an optimum at $\mathrm{pH} 8 \cdot 0$. Grows chemolithotrophically on CO. Utilizes $\mathrm{CO}$ as sole energy source, with equimolar formation of $\mathrm{H}_{2}$ and $\mathrm{CO}_{2}$ according to the equation $\mathrm{CO}+\mathrm{H}_{2} \mathrm{O} \rightarrow \mathrm{CO}_{2}+\mathrm{H}_{2}$. The presence of $200 \mathrm{mg}$ yeast extract or acetate $1^{-1}$ is required for growth. Elemental sulfur, thiosulfate, sulfate and nitrate do not stimulate growth and are not reduced during growth on CO. Does not grow organotrophically on peptone, yeast extract, starch, cellulose, cellobiose, sucrose, maltose, ribose, xylose, lactose, glucose, galactose, fructose, mannitol, sorbitol, pyruvate, acetate, formate, lactate, succinate, methanol, ethanol or glycerol. $\mathrm{H}_{2} / \mathrm{CO}_{2}$ gas mixture $(80: 20)$ does not support growth. Does not grow on $\mathrm{H}_{2}$ or $\mathrm{CO}$ with ferric iron. Does not grow on peptone, yeast extract, sucrose, pyruvate, acetate, formate, lactate, succinate, methanol, ethanol or glycerol, in the presence of elemental sulfur, sulfate, thiosulfate or ferric iron. Growth is completely inhibited by penicillin, erythromycin, streptomycin, rifampicin, vancomycin and tetracycline. The DNA G $+\mathrm{C}$ content of the type strain is $45 \cdot 4 \pm 1 \mathrm{~mol} \%$.

The type strain is strain $2204^{\mathrm{T}}\left(=\mathrm{DSM} 17129^{\mathrm{T}}=\mathrm{VKM}\right.$ B$2283^{\mathrm{T}}=$ JCM $\left.13258^{\mathrm{T}}\right)$, isolated from a hot spring of the Baikal Lake region. 


\section{Acknowledgements}

This work was supported by grant NATO LST.CLG.978269, by the Russian Foundation for Basic Research (projects 02-04-48-112) and by the Programs 'Biodiversity' and 'Molecular and Cell Biology' of the Russian Academy of Sciences.

\section{References}

Fardeau, M. L., Salinas, M. B., L'Haridon, S., Jeanthon, C., Verhé, F., Cayol, J. L., Patel, B. K., Garcia, J. L. \& Ollivier, B. (2004). Isolation from oil reservoirs of novel thermophilic anaerobes phylogenetically related to Thermoanaerobacter subterraneus: reassignment of $T$. subterraneus, Thermoanaerobacter yonseiensis, Thermoanaerobacter tengcongensis and Carboxydibrachium pacificum to Caldanaerobacter subterraneus gen. nov., sp. nov., comb. nov. as four novel subspecies. Int J Syst Evol Microbiol 54, 467-474.

Imachi, H., Sekiguchi, Y., Kamagata, Y., Ohashi, A. \& Harada, H. (2000). Cultivation and in situ detection of a thermophilic bacterium capable of oxidizing propionate in syntrophic association with hydrogenotrophic methanogens in a thermophilic methanogenic granular sludge. Appl Environ Microbiol 66, 3608-3615.

Jukes, T. H. \& Cantor, C. R. (1969). Evolution of protein molecules. In Mammalian Protein Metabolism, pp. 21-132. Edited by H. N. Munro. New York: Academic Press.

Kevbrin, V. V. \& Zavarzin, G. A. (1992). The influence of sulfur compounds on the growth of halophilic homoacetic bacterium Acetohalobium arabaticum. Microbiology (English translation of Mikrobiologiia) 61, 812-817.

Marmur, J. (1961). A procedure for the isolation of desoxyribonucleic acid from microorganisms. J Mol Biol 3, 208-218.

Marmur, J. \& Doty, P. (1962). Determination of the base composition of deoxyribonucleic acid from its thermal denaturation temperature. J Mol Biol 5, 109-118.

Rainey, F. A., Ward, N. L., Morgan, H. W., Toalster, R. \& Stackebrandt, E. (1993). Phylogenetic analysis of anaerobic thermophilic bacteria: aid for their reclassification. J Bacteriol 175, $4772-4779$.
Schlötelburg, C., von Wintzingerode, F., Hauck, R., Hegemann, W. \& Göbel, U. B. (2000). Bacteria of an anaerobic 1,2-dichloropropanedechlorinating mixed culture are phylogenetically related to those of other anaerobic dechlorinating consortia. Int J Syst Evol Microbiol 50, 1505-1511.

Slobodkin, A. I., Tourova, T. P., Kuznetsov, B. B., Kostrikina, N. A., Chernyh, N. A. \& Bonch-Osmolovskaya, E. A. (1999). Thermoanaerobacter siderophilus sp. nov., a novel dissimilatory $\mathrm{Fe}(\mathrm{III})$-reducing, anaerobic, thermophilic bacterium. Int $J$ Syst Bacteriol 49, 1471-1478.

Sokolova, T. G., Gonzalez, J. M., Kostrikina, N. A., Chernyh, N. A., Tourova, T. P., Kato, C., Bonch-Osmolovskaya, E. A. \& Robb, F. T. (2001). Carboxydobrachium pacificum gen. nov., sp. nov., a new anaerobic, thermophilic, CO-utilizing marine bacterium from Okinawa Trough. Int J Syst Evol Microbiol 51, 141-149.

Sokolova, T. G., Kostrikina, N. A., Chernyh, N. A., Tourova, T. P., Kolganova, T. V. \& Bonch-Osmolovskaya, E. A. (2002). Carboxydocella thermautotrophica gen. nov., sp. nov., a novel anaerobic, COutilizing thermophile from a Kamchatkan hot spring. Int J Syst Evol Microbiol 52, 1961-1967.

Sokolova, T. G., Gonzalez, J. M., Kostrikina, N. A., Chernyh, N. A., Slepova, T. V., Bonch-Osmolovskaya, E. A. \& Robb, F. T. (2004a). Thermosinus carboxydivorans gen. nov., sp. nov., a new anaerobic thermophilic, carbon-monoxide-oxidizing, hydrogenogenic bacterium from a hot pool of Yellowstone National Park. Int J Syst Evol Microbiol 54, 2353-2359.

Sokolova, T. G., Jeanthon, C., Kostrikina, N. A., Chernyh, N. A., Lebedinsky, A. V., Stackebrandt, E. \& Bonch-Osmolovskaya, E. A. (2004b). The first evidence of anaerobic CO oxidation coupled with $\mathrm{H}_{2}$ production by a hyperthermophilic archaeon isolated from a deep-sea hydrothermal vent. Extremophiles 8, 317-323.

Svetlichny, V. A., Sokolova, T. G., Gerhardt, M., Ringpfeil, M., Kostrikina, N. A. \& Zavarzin, G. A. (1991). Carboxydothermus hydrogenoformans gen. nov., sp. nov., a CO-utilizing thermophilic anaerobic bacterium from hydrothermal environments of Kunashir Island. Syst Appl Microbiol 14, 254-260.

Wolin, E. A., Wolin, M. J. \& Wolfe, R. S. (1963). Formation of methane by bacterial extracts. J Biol Chem 238, 2882-2886. 